\title{
USE OF SCALED SEMIVARIOGRAMS IN THE PLANNING SAMPLE OF SOIL CHEMICAL PROPERTIES IN SOUTHERN AMAZONAS, BRAZIL
}

\author{
Ivanildo Amorim de Oliveira(1), Milton César Costa Campos(2)*, José Marques Junior(1), \\ Renato Eleotério de Aquino(1), Daniel de Bortoli Teixeira(1) and Douglas Marcelo \\ Pinheiro da Silva(2)
}

\footnotetext{
(1) Universidade do Estado de São Paulo, Faculdade de Ciências Agrárias e Veterinárias, Departamento de Solos e Fertilizantes, Jaboticabal, São Paulo, Brasil.

(2) Universidade Federal do Amazonas, Instituto de Educação, Agricultura e Ambiente, Humaitá, Amazonas, Brasil.

* Corresponding author.

E-mail: mcesarsolos@gmail.com
}

\begin{abstract}
The lack of information concerning the variability of soil properties has been a major concern of researchers in the Amazon region. Thus, the aim of this study was to evaluate the spatial variability of soil chemical properties and determine minimal sampling density to characterize the variability of these properties in five environments located in the south of the State of Amazonas, Brazil. The five environments were archaeological dark earth (ADE), forest, pasture land, agroforestry operation, and sugarcane crop. Regular $70 \times 70 \mathrm{~m}$ mesh grids were set up in these areas, with 64 sample points spaced at $10 \mathrm{~m}$ distance. Soil samples were collected at the 0.0-0.1 m depth. The chemical properties of $\mathrm{pH}$ in water, $\mathrm{OM}, \mathrm{P}, \mathrm{K}, \mathrm{Ca}$, $\mathrm{Mg}, \mathrm{H}+\mathrm{Al}, \mathrm{SB}, \mathrm{CEC}$, and $\mathrm{V}$ were determined at these points. Data were analyzed by descriptive and geostatistical analyses. A large part of the data analyzed showed spatial dependence. Chemical properties were best fitted to the spherical model in almost all the environments evaluated, except for the sugarcane field with a better fit to the exponential model. ADE and sugarcane areas had greater heterogeneity of soil chemical properties, showing a greater range and higher sampling density; however, forest and agroforestry areas had less variability of chemical properties.
\end{abstract}

Keywords: geostatistics, Amazonian soils, archaeological dark earth, sampling density. 


\title{
RESUMO: USO DE SEMIVARIOGRAMAS ESCALONADOS NO PLANEJAMENTO AMOSTRAL DE ATRIBUTOS QUÍMICOS DO SOLO EM AMBIENTES NA REGIÃO SUL DO AMAZONAS
}

\begin{abstract}
A escassez de informações sobre o comportamento espacial dos atributos dos solos na região amazônica tem sido preocupação de muitos pesquisadores. Assim, este trabalho teve como objetivos avaliar a variabilidade espacial de atributos químicos do solo e determinar a densidade amostral mínima para caracterizar a variabilidade desses atributos em cinco ambientes amazônicos. Este estudo foi realizado ao sul do Estado do Amazonas, em área com terra preta arqueológica (TPA), floresta, pastagem, agrofloresta e cana-de-açúcar. Nessas áreas, foram estabelecidas malhas de $70 \times 70 \mathrm{~m}$, com espaçamento regular de $10 \mathrm{~m}$, totalizando 64 pontos em cada ambiente. Os solos foram coletados na profundidade de 0,0-0,10 m. Foram determinados os atributos químicos ( $\mathrm{HH}$ em água, $\mathrm{MO}, \mathrm{P}, \mathrm{K}, \mathrm{Ca}, \mathrm{Mg}, \mathrm{H}+\mathrm{Al}, \mathrm{SB}, \mathrm{CTC}$ e V). Os dados foram analisados utilizando-se técnicas de estatística descritiva e geoestatística. Grande parte dos atributos estudados apresentou estrutura de dependência espacial. O modelo esférico foi o que melhor se ajustou aos atributos químicos nos diferentes ambientes, onde somente a cana-de-açúcar evidenciou melhor ajuste ao modelo exponencial. As áreas de TPA e cana-de-açúcar mostraram maior heterogeneidade dos atributos químicos do solo, apresentando menor alcance e maior densidade amostral, e a área com floresta e agrofloresta apresentaram menor variabilidade dos atributos químicos.
\end{abstract}

Palavras-chave: geoestatística, solos da Amazônia, terra preta arqueológica, densidade amostral.

\section{INTRODUCTION}

Southern Amazonas is characterized by various landscapes, with natural and anthropogenic features. Within this context, areas of Archaeological Dark Earth (ADE) stand out, which include soils of high fertility. These soils are found throughout the entire Amazon region (Petersen et al., 2001; Lehmann et al., 2003; Glaser et al., 2004; Glaser, 2007; Woods et al., 2009). They are usually associated with bodies of water or higher altitude lands, with a notable characteristic of dark coloring and pottery fragments and/or lithic scatters mixed in the surface horizon (Kämpf and Kern, 2005).

In contrast, adjacent low fertility soils covered by forest play an important role in improving soil nutritional quality and physical properties. Consequently, studying these properties is essential for rational management, sustainable productivity, and prediction of the characteristics of forest ecosystems, since forest and soil are connected (Wojciechowski et al., 2009).

Other agroecosystems such as agroforestry, crops with pasture, and sugarcane fields are also in the region under study. However, there are no studies focusing on the variability of soil properties in these environments. In this regard, a main difficulty in studying spatial variability has been finding the appropriate sampling spacing, which, in some circumstances, may affect determination of the behavior of soil properties. Souza et al. (2006a) used the soil-topography relationship to define sampling density in estimating the variability of chemical properties in Oxisols, resulting in a decreased number of samples.
Sampling density is an important factor for soil property determination. Siqueira et al. (2010) stated that about $80-85 \%$ of errors in the application of agricultural inputs, such as fertilizers and soil amendments, may be attributed to poorly planned sampling. Thus, studying aspects of soil sampling to assist in defining the use of sampling techniques and in recommending them for different environments has been a constant concern of researchers (Webster and Oliver, 1990; Van Groenigen et al., 1999; Lark, 2000; Montanari et al., 2005, 2012; Siqueira et al., 2010).

For that reason, some techniques are employed so as to establish a standard for soil sampling that best expresses the soil properties. Many studies have been based on the results of geostatistical analysis (Souza et al., 2006b), using techniques such as the scaled semivariogram with Sanos software to assist sample design in other regions (Montanari et al., 2012). Nevertheless, these techniques have not yet been applied in southern Amazonas, though they are fundamentally important for mapping the spatial variability of soils and their properties.

Studies that generate results to assist soil fertility management in the state of Amazonas, Brazil are of great importance. Thus, we aimed to use scaled semivariograms to determine sample design of soil chemical properties in five different environments in southern Amazonas.

\section{MATERIAL AND METHODS}

The study was carried out on farms located in the south of the State of Amazonas, Brazil. These farms 
are near Santo Antônio do Matupi in municipality of Manicoré, AM, and in the municipality of Humaitá, AM. Soil mapping was carried out for five different environments: a natural environment or forest, soil with anthropic alterations or archaeological dark earth (ADE), pasture areas under brachiaria (Brachiaria brizanta) grass, an agroforestry environment, and a sugarcane crop.

The forest area at $7^{\circ} 54^{\prime} 44.5^{\prime \prime} \mathrm{S}, 61^{\circ} 31^{\prime} 44.7^{\prime \prime} \mathrm{W}$ and average altitude of $140 \mathrm{~m}$ is characterized as a Dense Tropical Rain Forest fragment with 20 to $50 \mathrm{~m}$ high trees. Adjacent to this, there is an area composed of Archaeological Dark Earth $(\mathrm{ADE})$ at $07^{\circ} 55^{\prime} 02.1^{\prime \prime} \mathrm{S}, 61^{\circ} 31^{\prime} 45.2^{\prime \prime} \mathrm{W}$, and average altitude of $102 \mathrm{~m}$, under maize cultivation for approximately 120 days at the time of this study. The pasture area at $07^{\circ} 54{ }^{\prime} 42^{\prime \prime S}$, $61^{\circ} 31^{\prime} 50^{\prime \prime} \mathrm{W}$ and an average altitude of $135 \mathrm{~m}$, has been under brachiaria (Brachiaria brizanta) grass for approximately 10 years in extensive pasture with around 1.0 animal ha-1. These areas are located in Manicoré. The agroforestry land is at $7^{\circ} 28^{\prime} 29^{\prime \prime} \mathrm{S}, 63^{\circ} 02^{\prime} 07^{\prime \prime} \mathrm{W}$, and average altitude of $63 \mathrm{~m}$, which has been under coffee, cocoa, palm tree, and andiroba, among other crops for around 20 years. The sugarcane field at $7^{\circ} 54^{\prime} 38^{\prime \prime} \mathrm{S}$ and $63^{\circ} 14^{\prime} 27^{\prime \prime} \mathrm{W}$ and average altitude of $70 \mathrm{~m}$ has been under burned sugarcane cropping for approximately 10 years. These latter two areas are located in the municipality of Humaitá (Figure 1). A detailed description of the characterization the physical properties was given by Aquino et al. (2015).

The Manicoré environments are on weathered soil originating from Rondonia granite from the Late Precambrian Eon (Brasil, 1978). The environments in Humaitá have old alluvial sediments as source material, which are chronologically from the Holocene Epoch (Brasil, 1978). According to the Köppen classification, the climate is rainy tropical with a short dry season $(\mathrm{Am})$, mean temperatures ranging from 25 to $27^{\circ} \mathrm{C}$, and mean annual rainfall from 2,250 to $2,750 \mathrm{~mm}$, with rains concentrated from October to June (Brasil, 1978). Soil types were classified as Red Ultisol in Manicoré and Haplic Cambisol in Humaitá (Embrapa, 2013).

A $70 \times 70$-m grid covering 0.49 ha was set up in these areas. Soil samples were collected at crossover points within the grid, with regular intervals of $10 \mathrm{~m}$, making for 64 sample points per grid (Figure 1). These points were georeferenced by Garmin Etrex GPS equipment (South American'69). Subsequently, soil samples were obtained from the 0.0-0.1-m layer for analysis of chemical properties.

Exchangeable $\mathrm{Ca}, \mathrm{Mg}$ and $\mathrm{K}$ contents, available $\mathrm{P}$, and potential acidity $(\mathrm{H}+\mathrm{Al})$ were determined by of the method of Raij et al. (2001). Based on chemical analysis, sum of bases (SB), cation-exchange capacity (CEC), and base saturation (V) were calculated.
The soil $\mathrm{pH}$ was measured with a potentiometer using the 1:2.5 ratio (soil:water) (Embrapa, 1997). Organic carbon content (OC) was monitored by the Walkley-Black method, which was modified by Yeomans and Bremner (1988), and organic matter $(\mathrm{OM})$ was estimated based on OC determination.

Data were analyzed by ANOVA and mean values were compared by the Tukey test at $5 \%$ probability using the Minitab statistical software (Minitab, 2000).

Data exploratory analysis was performed by calculating mean, median, coefficient of variation (CV), skewness, and the Kolmogorov-Smirnov test. The CV was calculated based on the Warrick and Nielsen (1980) criterion that classifies the CV as low (CV < $12 \%$ ), medium (from $12-24 \%$ ) and high (CV > $24 \%$ ).

Semivariograms were designed to determine spatial dependence through geostatistics (Matheron, 1963; Vieira et al., 1983; Isaaks and Srivastava, 1989). Under the theory of intrinsic hypothesis, the experimental semivariogram was estimated by equation 1 :

$$
\hat{\gamma}(h)=\frac{1}{2 N(h)} \sum_{i=1}^{N(h)}\left[Z\left(x_{i}\right)=Z\left(x_{i}+h\right)\right]^{2}
$$

where $\gamma(\mathrm{h})=$ semivariance value at distance $\mathrm{h} ; \mathrm{N}(\mathrm{h})$ = number of pairs of experimental $\mathrm{Z}$ observations; $\mathrm{Z}\left(\mathrm{x}_{\mathrm{i}}\right)=$ value of the $\mathrm{Z}$ property at location $\mathrm{x}_{\mathrm{i}}$; and $\mathrm{Z}\left(\mathrm{x}_{\mathrm{i}}+\mathrm{h}\right)=$ value of the $\mathrm{Z}$ property separated by a distance $\mathrm{h}$ from location $\mathrm{x}_{\mathrm{i}}$.

The scaled semivariogram was built based on parameters of experimental semivariograms of soil properties, which were scaled through division of semivariances by statistical variance (Guimarães, 1993; Vieira et al., 1997). In this study, semivariograms were scaled to reduce them to the same scale, facilitating comparison among results of different variables. Moreover, we aimed to represent several semivariograms simultaneously to better understand patterns of similarity and causes of spatial variability (Ceddia et al., 2009).

Spherical (Equation 2) and exponential (Equation 3) models were fitted to the scaled experimental semivariograms, which were identified as Sph. $\left(\mathrm{C}_{0}, \mathrm{C}_{1}+\mathrm{C}_{0},\left[\left(\mathrm{C}_{0} /\left(\mathrm{C}_{0}+\mathrm{C}_{1}\right) \times 100\right]\right.\right.$, a, $\left.\mathrm{R}^{2}\right)$ :

$$
\begin{aligned}
& \left\{\begin{array}{l}
\hat{\gamma}(h)=C_{0}+C_{1}\left[\frac{3}{2}\left(\frac{h}{a}\right) \cdot \frac{1}{2}\left(\frac{h}{a}\right)^{3}\right], \text { se } 0<h<a \\
\hat{\gamma}(h)=C_{0}+C_{1}, \text { se } h \geq a
\end{array}\right. \\
& \gamma(h)=C_{0}+C_{1}\left[1-\exp \left(-\frac{3 h}{a}\right)\right], h \geq 0
\end{aligned}
$$

where $\mathrm{C}_{0}=$ nugget effect; $\mathrm{C}_{0}+\mathrm{C}_{1}=$ sill; $\mathrm{h}=$ distance between experimental observations; and a $=$ spatial dependence range. 


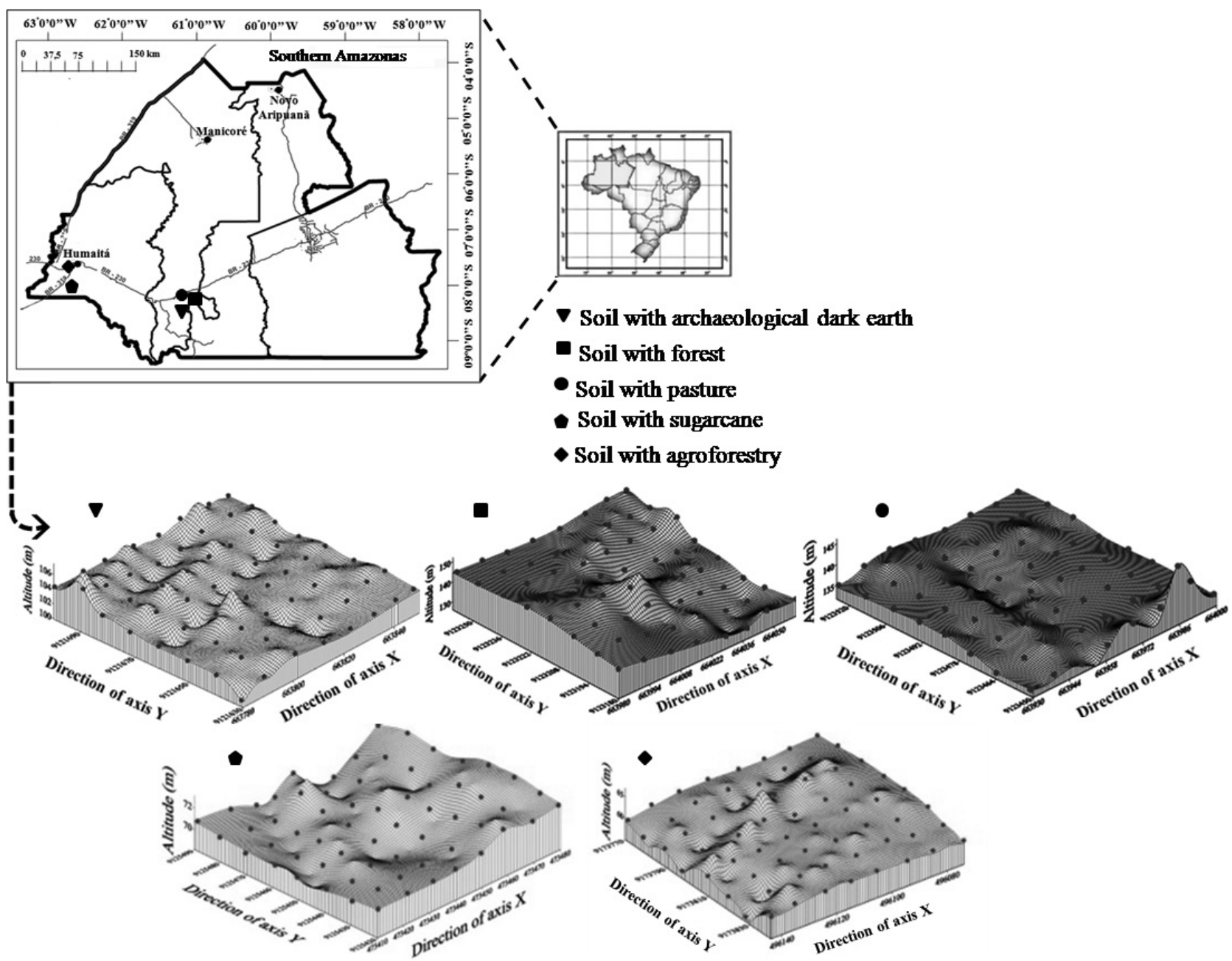

Figure 1. Area location and Digital Elevation Model (DEM) of the environments in southern Amazonas.

Subsequently, scaled semivariograms served as an information source to calculate the minimum number of soil samples to determine the variability of all properties within the areas under study (Equation 4):

$$
\mathrm{N}=\frac{\mathrm{A}}{\left(\mathrm{a}^{2}\right) / 10000}
$$

where $\mathrm{N}=$ minimum number of samples necessary to determine a sample grid; $\mathrm{A}=$ total area (ha); and $\mathrm{a}=$ semivariogram range $(\mathrm{m})$.

In analysis of the degree of spatial dependence (DSD) of the variables under study, we used the classification proposed by Cambardella et al. (1994) in which dependence values of $\left[\left(\mathrm{C}_{0} /\left(\mathrm{C}_{0}+\mathrm{C}_{1}\right) \times 100\right]\right.$ lower than $25 \%$ are considered strong, values from 25 to $75 \%$ are moderate, and values greater than $75 \%$ have poor dependence.

\section{RESULTS AND DISCUSSION}

Mean values of the chemical properties were significantly different among the environments under study (Table 1). The ADE values in the 0.0-0.1-m layer were greater than the values for the forest, pasture, agroforestry and sugarcane lands, which highlighted the improved quality and greater fertility of the soils with ADE.

For ADE, higher values for OM, SB, and V were noted, as well as for the properties of $\mathrm{pH}, \mathrm{P}, \mathrm{Ca}, \mathrm{Mg}$, and CEC. In contrast, other environments have a higher potential acidity (Table 1). This can explain the high fertility of ADE in relation to adjacent lands because, according to Lehmann et al. (2003) and Glaser (2007), ADE soils generally have high fertility, with high levels of $\mathrm{P}, \mathrm{Ca}, \mathrm{Mg}, \mathrm{Zn}$, and $\mathrm{Mn}$, and high content of stable organic matter. On the other hand, Cunha et al. (2009) argued that the high fertility of $\mathrm{ADE}$ is strongly related to the molecular 
Table 1. Means test of chemical properties for the environments evaluated from the municipalities of Humaitá and Manicoré in southern Amazonas

\begin{tabular}{|c|c|c|c|c|c|}
\hline Property & Forest & $\operatorname{ADE}(1)$ & Pasture & Agroforestry & Sugarcane \\
\hline & \multicolumn{3}{|c|}{ Red Ultisol } & \multicolumn{2}{|c|}{ Haplic Cambisol } \\
\hline $\mathrm{pH}\left(\mathrm{H}_{2} \mathrm{O}\right)$ & $3.97 \mathrm{C}$ & $6.27 \mathrm{~A}$ & $4.30 \mathrm{~B}$ & $3.78 \mathrm{C}$ & $4.43 \mathrm{~B}$ \\
\hline $\mathrm{H}+\mathrm{Al}\left(\mathrm{mmol}_{\mathrm{c}} \mathrm{kg}^{-1}\right)$ & $74.92 \mathrm{C}$ & $28.29 \mathrm{D}$ & $61.13 \mathrm{BC}$ & $189.52 \mathrm{~A}$ & 89.64 B \\
\hline $\mathrm{OM}\left(\mathrm{g} \mathrm{dm}^{-3}\right)$ & $18.66 \mathrm{C}$ & $68.19 \mathrm{~A}$ & $27.47 \mathrm{~B}$ & $20.58 \mathrm{C}$ & $30.48 \mathrm{~B}$ \\
\hline $\mathrm{P}(\mathrm{mg} \mathrm{dm}-3)$ & $6.09 \mathrm{~B}$ & $309.4 \mathrm{~A}$ & $4.61 \mathrm{~B}$ & $8.19 \mathrm{~B}$ & $6.36 \mathrm{~B}$ \\
\hline $\mathrm{K}^{+}\left(\mathrm{mmol}_{\mathrm{c}} \mathrm{kg}^{-1}\right)$ & $1.66 \mathrm{~A}$ & $1.72 \mathrm{~A}$ & $1.71 \mathrm{~A}$ & $1.11 \mathrm{~B}$ & $0.49 \mathrm{C}$ \\
\hline $\mathrm{Ca}^{2+}\left(\mathrm{mmol}_{\mathrm{c}} \mathrm{kg}^{-1}\right)$ & $4.77 \mathrm{C}$ & $166.02 \mathrm{~A}$ & $10.27 \mathrm{BC}$ & $2.39 \mathrm{C}$ & $14.58 \mathrm{~B}$ \\
\hline $\mathrm{Mg}^{2+}\left(\mathrm{mmol}_{\mathrm{c}} \mathrm{kg}^{-1}\right)$ & $2.52 \mathrm{D}$ & $29.45 \mathrm{~A}$ & $4.64 \mathrm{C}$ & $1.36 \mathrm{D}$ & $8.06 \mathrm{~B}$ \\
\hline $\mathrm{SB}\left(\mathrm{mmol}_{\mathrm{c}} \mathrm{kg}^{-1}\right)$ & $8.94 \mathrm{C}$ & $197.19 \mathrm{~A}$ & $16.62 \mathrm{BC}$ & $4.86 \mathrm{C}$ & $23.13 \mathrm{~B}$ \\
\hline $\mathrm{CEC}\left(\mathrm{mmol}_{\mathrm{c}} \mathrm{kg}^{-1}\right)$ & $83.86 \mathrm{D}$ & $225.49 \mathrm{~A}$ & $77.74 \mathrm{D}$ & 194.37 B & $112.77 \mathrm{C}$ \\
\hline V (\%) & $11.11 \mathrm{C}$ & $87.20 \mathrm{~A}$ & $21.99 \mathrm{~B}$ & $2.52 \mathrm{D}$ & $21.06 \mathrm{~B}$ \\
\hline
\end{tabular}

(1) ADE: Archaeological Dark Earth. H+Al: potential acidity; OM: organic matter; SB: sum of bases; CEC: cation-exchange capacity; and V: base saturation. Mean values followed by the same uppercase letter at the same depth do not differ from each other significantly by the Tukey test at $5 \%$.

characteristics of the alkali-soluble fraction within organic carbon $(\mathrm{OC})$ content. These same authors found that $A$ horizons in anthropogenic Amazon soils have higher total $\mathrm{C}$ content compared to adjacent non-anthropogenic soils.

Most of the properties of the systems under study have similar mean and median values (Table 2), indicating near-normal distribution, which is considered acceptable in geostatistical studies (Gonçalves and Folegatti, 2002). However, some properties have values distant from zero, indicating asymmetric distribution, which is confirmed by high asymmetry values, showing that they are affected by extreme values.

Results of the Kolmogorov-Smirnov test indicated normality for some properties in the lands under study (Table 2). However, most of the variables showed no data normality in the different environments, greater occurring in $\mathrm{ADE}$, agroforestry and sugarcane. Nonetheless, according to Cressie (1991) and Isaaks and Srivastava (1989), data normality is not required for geostatistics; it is enough that the distribution not have very elongated tails, which could compromise kriging estimates, which are based on mean values.

The CVs indicated low variability $(\mathrm{CV}<12 \%)$ for $\mathrm{pH}$ in all management practices, $\mathrm{V}$ in ADE, CEC in pasture, and $\mathrm{H}+\mathrm{Al}$ and $\mathrm{CEC}$ in agroforestry (Table 2). There were medium CVs $(12 \%<\mathrm{CV}>24 \%)$ for $\mathrm{H}+\mathrm{Al}, \mathrm{OM}, \mathrm{Ca}, \mathrm{CEC}, \mathrm{Mg}, \mathrm{SB}$ in $\mathrm{ADE} ; \mathrm{H}+\mathrm{Al}$, and $\mathrm{OM}$ in pasture areas; $\mathrm{OM}, \mathrm{K}, \mathrm{SB}, \mathrm{P}$, and $\mathrm{Ca}$ in agroforestry; and $\mathrm{H}+\mathrm{Al}, \mathrm{CEC}, \mathrm{OM}$, and $\mathrm{K}$ in sugarcane. The other variables had high values (CV $>24 \%$ ). It was observed that sugarcane, agroforestry, and $\mathrm{ADE}$ had more variables with high CVs, indicating high variability of soil properties (Table 2).
Montanari et al. (2012), Souza et al. (2004), and Wortmann et al. (2009) also found low, moderate, and high CVs for some chemical properties, which may underscore the influence of fertilizer management in cropping systems.

Nevertheless, CV allows comparison of variability among samples of variables with different units, but it does not allow analysis of spatial variability of soil properties or their spatial standard (Camargo et al., 2008). For that purpose, soils chemical properties were subjected to geostatistical analysis to which had spatial correlation, being expressed by fitted semivariogram models (Figure 2). The spherical model was predominant for ADE, forest, agroforestry, and pasture areas. For the sugarcane crop, the exponential model best fit the data (Figure 2e).

According to Carvalho et al. (2002), the spherical model prevails in studies in soil science. In contrast, McBratney and Webster (1983), Bertolani and Vieira (2001), and Siqueira et al. (2010) emphasize spherical and exponential models as those most used in soil and environmental sciences. The fitting of models to properties accounts for the behavior of the properties. According to Isaaks and Srivastava (1989), exponential models are better fitted to erratic phenomena on small scales, whereas spherical models describe properties with high spatial continuity, i.e., less erratic at short distances.

Some variables showed no spatial dependence structure, characterized by the pure nugget effect model (PNE). When the variable under study is spatially independent, the nugget effect is equal to the sill. The PNE could occur due to measurement and sampling errors or undetected micro-variations when taking into account sample spacing larger 
Table 2. Descriptive statistics for soil chemical properties in the municipalities of Humaitá and Manicoré in southern Amazonas

\begin{tabular}{|c|c|c|c|c|c|c|c|c|c|c|}
\hline Parameter & $\mathrm{pH}\left(\mathrm{H}_{2} \mathrm{O}\right)$ & $\mathrm{H}+\mathrm{Al}$ & OM & $\mathbf{P}$ & $\mathbf{K}^{+}$ & $\mathrm{Ca}^{2+}$ & $\mathrm{Mg}^{2+}$ & SB & CEC & $\mathrm{V}$ \\
\hline & \multicolumn{10}{|c|}{ Forest - Red Ultisol } \\
\hline Mean & 3.97 & 74.92 & 18.66 & 6.09 & 1.66 & 4.77 & 2.52 & 8.94 & 83.86 & 11.11 \\
\hline Median & 3.90 & 88.00 & 20.50 & 5.50 & 1.50 & 3.00 & 2.00 & 7.05 & 93.95 & 8.40 \\
\hline CV (\%) & 4.79 & 29.42 & 35.29 & 36.13 & 67.25 & 101.96 & 50.58 & 69.08 & 26.16 & 68.34 \\
\hline Ass. & 0.74 & -0.21 & -0.28 & 0.49 & 2.97 & 4.50 & 1.80 & 3.27 & -0.37 & 2.99 \\
\hline \multirow[t]{2}{*}{$\mathrm{Nt}$} & $0.11^{*}$ & $0.15^{*}$ & $0.13^{*}$ & $0.08^{\mathrm{ns}}$ & $0.14^{*}$ & $0.28^{*}$ & $0.15^{*}$ & $0.27^{*}$ & $0.19^{*}$ & $0.26^{*}$ \\
\hline & \multicolumn{10}{|c|}{ Archaeological Dark Earth - Red Ultisol } \\
\hline Mean & 6.27 & 28.29 & 68.19 & 309.4 & 1.72 & 166.02 & 29.45 & 197.19 & 225.49 & 87.20 \\
\hline Median & 6.20 & 29.50 & 68.00 & 298.5 & 1.40 & 164.50 & 30.00 & 195.20 & 227.65 & 86.80 \\
\hline CV (\%) & 4.71 & 23.46 & 19.86 & 27.93 & 82.30 & 16.10 & 22.04 & 14.80 & 12.30 & 4.11 \\
\hline Ass. & 0.58 & -0.08 & -0.26 & 0.53 & 4.66 & -0.51 & 0.27 & -0.46 & -0.61 & -0.20 \\
\hline \multirow[t]{2}{*}{$\mathrm{Nt}$} & $0.09^{\mathrm{ns}}$ & $0.06^{\mathrm{ns}}$ & $0.06^{\mathrm{ns}}$ & $0.07^{\mathrm{ns}}$ & $0.26^{*}$ & $0.06^{\mathrm{ns}}$ & $0.05^{\mathrm{ns}}$ & $0.09^{\mathrm{ns}}$ & $0.08^{\mathrm{ns}}$ & $0.08^{\text {ns }}$ \\
\hline & \multicolumn{10}{|c|}{ Pasture - Red Ultisol } \\
\hline Mean & 4.30 & 61.13 & 27.47 & 4.61 & 1.71 & 10.27 & 4.64 & 16.62 & 77.74 & 21.99 \\
\hline Median & 4.25 & 64.00 & 27.00 & 4.00 & 1.30 & 8.00 & 4.00 & 13.45 & 77.80 & 17.35 \\
\hline CV (\%) & 6.09 & 22.23 & 13.59 & 25.23 & 67.30 & 64.06 & 38.85 & 51.38 & 10.40 & 55.81 \\
\hline Ass. & 1.38 & -0.48 & 0.43 & 1.82 & 1.58 & 1.69 & 0.78 & 1.39 & -0.34 & 1.32 \\
\hline \multirow[t]{2}{*}{$\mathrm{Nt}$} & $0.11^{*}$ & $0.06^{\mathrm{ns}}$ & $0.07^{\mathrm{ns}}$ & $0.07^{\mathrm{ns}}$ & $0.15^{*}$ & $0.16^{*}$ & $0.08^{\mathrm{ns}}$ & $0.17^{*}$ & $0.07^{\mathrm{ns}}$ & $0.18^{*}$ \\
\hline & \multicolumn{10}{|c|}{ Agroforestry - Haplic Cambisol } \\
\hline Mean & 3.78 & 189.52 & 20.58 & 8.19 & 1.11 & 2.39 & 1.36 & 4.86 & 194.37 & 2.52 \\
\hline Median & 3.80 & 185.00 & 20.50 & 8.00 & 1.10 & 2.00 & 1.00 & 4.15 & 191.40 & 2.20 \\
\hline CV (\%) & 1.53 & 9.26 & 15.48 & 18.96 & 21.78 & 23.11 & 35.58 & 23.73 & 8.98 & 26.24 \\
\hline Ass. & -0.48 & -0.51 & 0.79 & 0.57 & 0.59 & 1.03 & 0.60 & 0.67 & -0.51 & 0.75 \\
\hline \multirow[t]{2}{*}{$\mathrm{Nt}$} & $0.06^{\mathrm{ns}}$ & $0.05^{\mathrm{ns}}$ & $0.09 \mathrm{~ns}$ & $0.04^{\mathrm{ns}}$ & $0.07 \mathrm{~ns}$ & $0.09 \mathrm{~ns}$ & $0.10^{\mathrm{ns}}$ & $0.28^{*}$ & $0.24^{*}$ & $0.18^{*}$ \\
\hline & \multicolumn{10}{|c|}{ Sugarcane - Haplic Cambisol } \\
\hline Mean & 4.43 & 89.64 & 30.48 & 6.36 & 0.49 & 14.58 & 8.06 & 23.13 & 112.77 & 21.06 \\
\hline Median & 4.50 & 80.00 & 30.50 & 7.00 & 0.50 & 15.00 & 8.00 & 23.30 & 107.50 & 21.6 \\
\hline CV (\%) & 3.39 & 23.52 & 20.52 & 24.64 & 22.98 & 28.63 & 35.21 & 29.90 & 16.27 & 32.44 \\
\hline Ass. & -0.85 & 2.96 & -0.05 & -0.06 & 0.02 & 0.07 & 0.75 & 0.33 & 3.30 & -0.12 \\
\hline $\mathrm{Nt}$ & $0.05^{\mathrm{ns}}$ & $0.15^{*}$ & $0.07_{\mathrm{ns}}$ & $0.04^{\mathrm{ns}}$ & $0.04^{\mathrm{ns}}$ & $0.03^{\mathrm{ns}}$ & $0.07^{\mathrm{ns}}$ & $0.06^{\mathrm{ns}}$ & $0.19^{*}$ & $0.05^{*}$ \\
\hline
\end{tabular}

CV: coefficient of variation; Ass.: asymmetry coefficient; Nt: normality test, at $5 \%$ significance by the Kolmogorov-Smirnov test; $\mathrm{H}+\mathrm{Al}$ : potential acidity; OM: organic matter; SB: sum of bases; CEC: cation exchange capacity; and V: base saturation. * and ns: significant and non-significant, respectively.

than that necessary to detect spatial dependence (Cambardella et al., 1994; Zanão Júnior et al., 2010).

Degree of spatial dependence (DSD), for scaled semivariograms expressed by the ratio between the nugget effect $\left(\mathrm{C}_{0}\right)$ and the sill $\left(\mathrm{C}_{0}+\mathrm{C}_{1}\right)$ (Cambardella et al., 1994), was classified as moderate for all environments under study (Figure 2). As suggested by Cambardella et al. (1994), variables with moderate spatial dependence may be due to soil homogeneity.

The range of the scaled semivariograms show that $\mathrm{ADE}$ and sugarcane areas have lower spatial dependence and greater variability, with ranges of $35 \mathrm{~m}$, even in different soil classes. In this sense, range values are important measures for planning and experimental evaluations, as range can assist in sampling procedure definition (McBraitney and Webster, 1983; Souza et al., 2009).

In this respect, the range of the scaled semivariogram was used to estimate the minimum number of samples to characterize soil spatial variability of soil chemical properties (Table 3). The ADE and sugarcane environments are more heterogeneous in chemical properties and so they 
(a) Forest
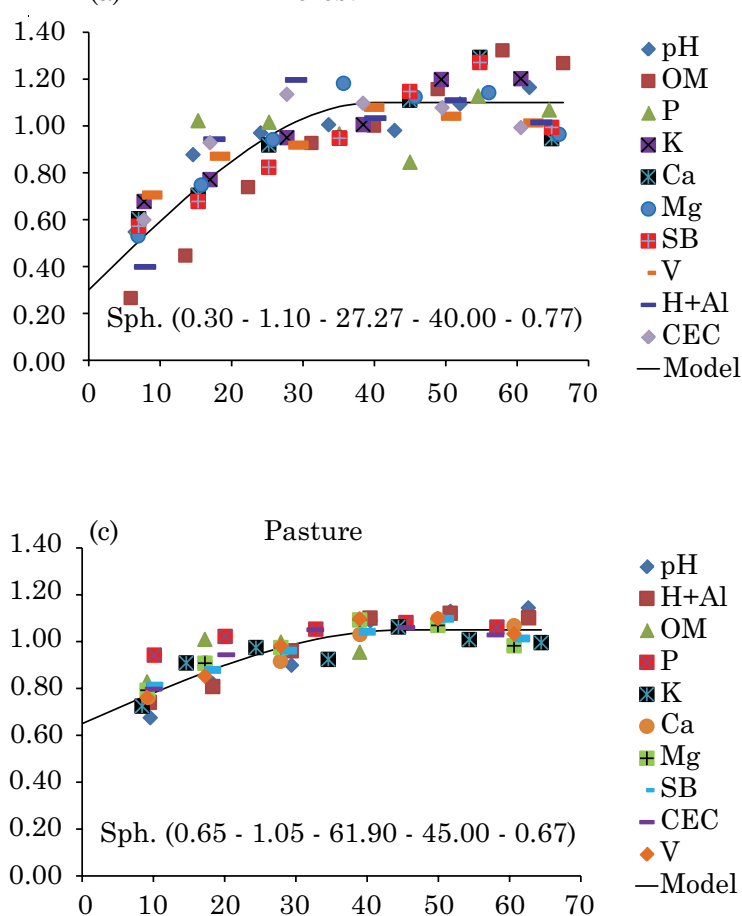

(b) Archaeological Dark Earth

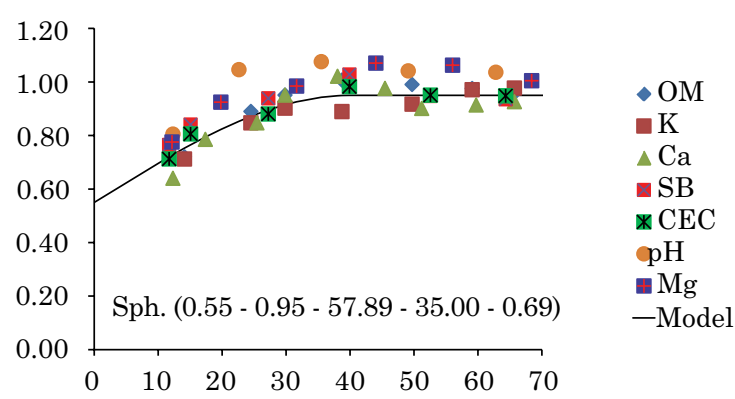

(d) Agroforestry

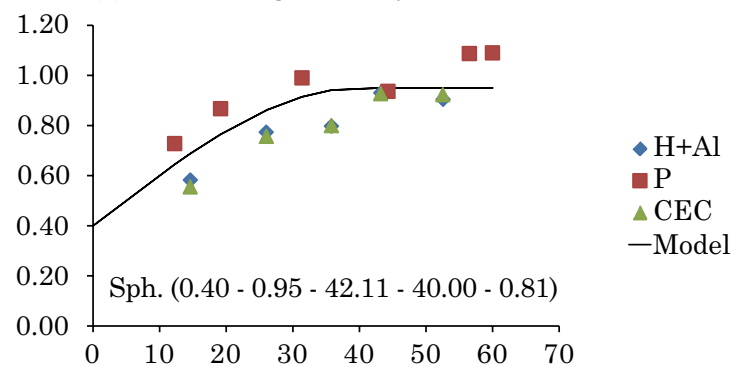

(e) Sugarcane

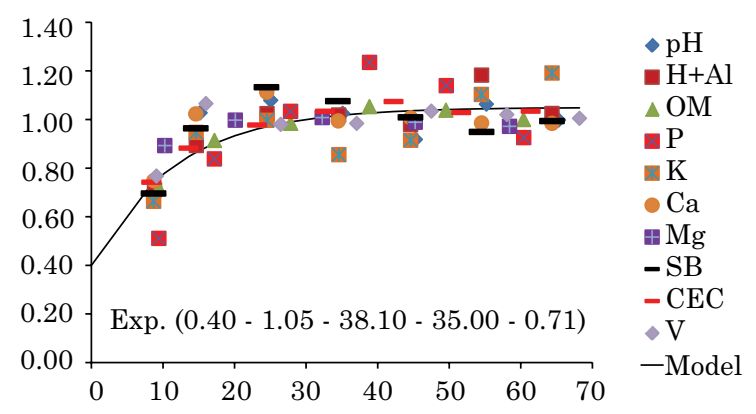

Figure 2. Scaled semivariograms for chemical properties of environments in municipalities of Humaitá and Manicoré in southern Amazonas. Exp.: exponential; Sph.: spherical; [model (nugget effect - sill - DSD - $\mathbf{R}^{2}$ - range - residue)]. DSD: degree of spatial dependence; $R^{2}$ : coefficient of determination.

require a higher number of samples to analyze variability with a sampling density of eight points ha-1 and spacing of $35 \mathrm{~m}$. This aspect may be connected to intensive use of the soil surface layers, which are more heterogeneous. In contrast, the agroforestry area had lower variability for soil chemical properties; consequently, the sampling density required is lower than in the other environments (Table 3 ).

It may be seen that pasture land and forest had the same behavior, with a sampling density of six points ha- ${ }^{-1}$. Since these areas have the same soil class, this result may be due to the short time that establishment of the extensive pasture system had to cause changes in soil characteristics (Barreto et al., 2006), as well as the proper use and management of pasture areas by the producer.

In this study, it was possible to estimate spacing and sampling density values in different environments in southern Amazonas. The ADE and sugarcane fields required greater sampling density (eight points ha-1). These values may serve as basis for further studies on soil mapping since these environments represent the region and there are few studies of this nature for these environments. 
Table 3. Minimum sampling density and spacing based on the range estimated by scaled semivariograms for soil chemical properties in different environments studied in southern Amazonas

\begin{tabular}{|c|c|c|c|c|c|}
\hline Sample design & Forest & ADE & Pasture & Agroforestry & Sugarcane \\
\hline & \multicolumn{3}{|c|}{ Red Ultisol } & \multicolumn{2}{|c|}{ Haplic Cambisol } \\
\hline Sampling density (points ha-1) & 6 & 8 & 6 & 5 & 8 \\
\hline Spacing $(\mathrm{m})$ & 40 & 35 & 40 & 45 & 35 \\
\hline
\end{tabular}

ADE: archaeological dark earth.

\section{CONCLUSIONS}

Archaeological Dark Earth (ADE) had better chemical quality with the lowest potential acidity.

The spherical model best fitted the chemical properties in the different environments, except for sugarcane, which was better served by the exponential model.

$\mathrm{ADE}$ and sugarcane had the greatest heterogeneity of chemical properties and, consequently, a lower range and the higher sampling density. The agroforestry area had the lowest variability of chemical properties.

\section{ACKNOWLEDGMENTS}

The authors would like to thank the FAPEAM, SECTI-AM, and FAPESP for financial support.

\section{REFERENCES}

Aquino RE, Campos MCC, Marques Junior J, Oliveira IA, Teixeira DB, Cunha JM. Use of Scaled Semivariograms in the Planning Sample of Soil Physical Properties in Southern Amazonas, Brazil. R Bras Ci Solo. 2015;39:21-30.

Barreto AC, Lima FHS, Freire MBGS, Araújo QR, Freire FJ. Características químicas e físicas de um solo sob floresta, sistema agroflorestal e pastagem no Sul da Bahia. R Caatinga. 2006;19:415-25.

Bertolani FC, Vieira SR. Variabilidade espacial da taxa de infiltração de água e da espessura do horizonte A, em um Argissolo Vermelho-Amarelo, sob diferentes usos. R Bras Ci Solo. 2001;25:987-95.

Brasil. Ministério das Minas e Energia. Projeto RadamBrasil, folha SB. 20, Purus. Rio de Janeiro: Ministério das Minas e Energia, 1978.

Camargo LA, Marques Júnior J, Pereira GT, Horvat RA. Variabilidade espacial de atributos mineralógicos de um Latossolo sob diferentes formas do relevo. II - Correlação espacial entre mineralogia e agregados. R Bras Ci Solo. 2008;32:2279-88.

Cambardella CA, Moorman TB, Novak JM, Parkin TB, Karlen DL, Turco R, Konopka AE. Field-scale variability of soil properties in Central Iowa Soil. Soil Sci Soc Am J. 1994;58:1501-11.
Carvalho M, Soratto RP, Freddi OS. Variabilidade espacial de atributos físicos em um Latossolo Vermelho Distrófico sob preparo convencional em Selvíria, Estado de Mato Grosso do Sul. Acta Sci. 2002;24:1353-61.

Ceddia MB, Vieira SR, Villela ALO, Mota LS, Anjos LHC, Carvalho DF. Topography and spatial variability of soil physical properties. Sci Agric. 2009;66:338-52.

Cressie N. Statistics for spatial data. New York: John Wiley; 1991.

Cunha TJF, Madari BE, Canelas LP, Ribeiro LP, Benites VM, Santos GA. Soil organic matter and fertility of anthropogenic dark earths (Terra Preta de Índio) in the Brazilian Amazon basin. $\mathrm{R}$ Bras Ci Solo. 2009;33:85-93.

Empresa Brasileira de Pesquisa Agropecuária - Embrapa. Manual de métodos de análise de solo. Rio de Janeiro: Centro Nacional de Pesquisa de Solos; 1997.

Empresa Brasileira de Pesquisa Agropecuária - Embrapa. Sistema brasileiro de classificação de solos. 3a ed. Brasília; 2013.

Glaser B. Prehistorically modified soils of central Amazonia: A model for sustainable agriculture in the twenty-first century. Phil Trans Royal Soc B. 2007;362:187-96.

Glaser B, Guggenberger G, Zech W. Identifying the preColumbian anthropogenic input on present soil properties of Amazonian Dark Earths (Terra Preta). In: Glaser B, Woods WI, editors. Amazonian Dark Earths: Explorations in space and time. Berlin: Springer; 2004. p.145-58.

Gonçalves ACA, Folegatti MV. Correlação espacial entre retenção de água e textura do solo, para fins de manejo de irrigação. Eng Agríc. 2002;22:296-303.

Guimarães EC. Variabilidade espacial da umidade e da densidade do solo em um Latossolo Roxo [dissertação]. Campinas: Universidade de Campinas; 1993.

Isaaks EH, Srivastava RM. An introduction to applied geostatistics. New York: Oxford University Press; 1989.

Kämpf N, Kern DC. O solo como registro da ocupação humana pré-histórica na Amazônia. In: Vidal-Torrado P, Alleoni LRF, Cooper M, Silva AP, editores. Tópicos em ciência do solo. Viçosa, MG: Sociedade Brasileira de Ciência do Solo; 2005. v.4, p.277-320.

Lark RM. Designing sampling grids from imprecise information on soil variability, an approach based on the fuzzy kriging variance. Geoderma. 2000;98:35-9.

Lehmann J, Kern DC, Glaser B, Woods W, editors. Amazonian Dark Earths: Origin, properties, management. Dodrecht: Kluwer Academic Publishers; 2003.

McBratney AB, Webster R. How many observations are needed for regional estimation of soil properties. Soil Sci. 1983;135:177-83.

Matheron G. Principles of geostatistics. Econ Geol. 1963;58:1246-66. 
Minitab Release 14.1. Statistical Software [CD-ROM]. Quebec: Canadá; 2000.

Montanari R, Marques Júnior J, Pereira GT, Souza ZM. Forma da paisagem como critério para otimização amostral de Latossolos sob cultivo de cana-de-açúcar. Pesq Agropec Bras. 2005;40:69-77.

Montanari R, Souza GSA, Pereira GT, Marques J, Siqueira DS, Siqueira GM. The use of scaled semivariograms to plan soil sampling in sugarcane fields. Precision Agric. 2012;13:542-52.

Petersen JB, Neves EG, Heckenberger MJ. Gift from the past. Terra preta and prehistoric Amerindian occupation in Amazonia. In: McEwan C, editor. Unknown Amazonia. London: The British Museum Press; 2001. p.86-105.

Raij BV, Andrade JC, Cantarella H, Quaggio JA, editores. Análise química para avaliação da fertilidade do solo. Campinas: Instituto Agronômico; 2001.

Siqueira DS, Marques Júnior J, Pereira GT. The use of landforms to predict the variability of soil and orange attributes. Geoderma. 2010;155:55-66.

Souza ZM, Marques Júnior J, Pereira GT. Geoestatística e atributos do solo em áreas cultivadas com cana-de-açúcar. Ci Rural. 2009;40:48-56.

Souza ZM, Marques Júnior J, Pereira GT, Montanari R, Campos MCC. Amostragem de solo para determinação de atributos químicos e físicos em área com variação nas formas do relevo. Científica. 2006;34:249-56.

Souza ZM, Marques Júnior J, Pereira GT. Variabilidade espacial da estabilidade de agregados e matéria orgânica em solos de relevos diferentes. Pesq Agropec Bras. 2004;39:491-9.

Souza ZM, Marques Júnior J, Pereira GT, Montanari R. Otimização amostral de atributos de Latossolos considerando aspectos solo-relevo. Ci Rural. 2006b;36:829-36.

Souza ZM, Marques Júnior J, Pereira GT, Moreira LF. Variabilidade espacial do $\mathrm{pH}, \mathrm{Ca}, \mathrm{Mg}$ e V\% do solo em diferentes formas do relevo sob cultivo de cana-de-açúcar. Ci Rural. 2004;34:1763-71.

Van Groenigen JW, Siderius W, Stein A. Constrained optimisation of soil sampling for minimisation of the kriging variance. Geoderma. 1999;87:239-59.

Vieira SR, Tillotson PM, Biggar JW, Nielsen DR. Scaling of semivariograms and the kriging estimation of field-measured properties R Bras Ci Solo. 1997;21:525-33.

Vieira SR, Hatfield JL, Nielsen DR, Biggar JW. Geoestatiscal theory and application to variability of some agronomical properties. Hilgardia. 1983;51:1-75.

Warrick AW, Nielsen DR. Spatial variability of soil physical properties in the field. In: Hillel D, editor. Applications of soil physics. New York: Academic Press; 1980. p.319-44.

Webster R, Oliver MA. Statistical methods in soil and land resource survey. Oxford: Oxford University Press; 1990.

Wojciechowski JC, Schumacher MV, Pires CAF, Madruga PRA, Kilca RV, Brun EJ, Silva CRS, Vaccaro S, Rondon Neto RM. Geoestatística aplicada ao estudo das características físico-químicas do solo em áreas de floresta estacional decidual. Ci Flor. 2009;19:383-91.

Woods WI, Teixeira WG, Lehmann J, Steiner C, Winklerprins AMGA, Rebellato L., eds. Amazonian Dark Earths: Wim Sombroeks Vision. Berlin: Springer; 2009.

Wortmann CS, Dobermann A, Ferguson RB, Hergert GW, Shapiro CA, Tarkalson DD, Walters DT. High yield corn response to applied phosphorus, potassium, and sulfur in Nebraska. Agron. J., 101:546-555, 2009.

Yeomans JC, Bremner JM. A rapid and precise method for routine determination of organic carbon in soil. Commun Soil Sci Plant Anal. 1988;19:1467-76.

Zanão Júnior LA, Lana RMQ, Guimarães EC. Variabilidade espacial do $\mathrm{pH}$, teores de matéria orgânica e micronutrientes em profundidade em um Latossolo Vermelho sob semeadura direta. Ci Rural. 2007;37:1000-7. 